\title{
FUELING INCUBATION: DIFFERENTIAL USE OF BODY STORES IN ARCTIC- AND TEMPERATE-BREEDING BARNACLE GEESE (BRANTA LEUCOPSIS)
}

\author{
Götz Eichhorn, ${ }^{1,4}$ Henk P. van der Jeugd, ${ }^{2}$ Harro A. J. Meijer, ${ }^{3}$ \\ AND RUdOLF H. DRENT ${ }^{1,5}$ \\ ${ }^{1}$ Animal Ecology Group, Centre for Ecological and Evolutionary Studies, University of Groningen, Groningen, The Netherlands; \\ ${ }^{2}$ Dutch Centre for Avian Migration and Demography, Royal Netherlands Academy of Arts and Sciences, Heteren, The Netherlands; and \\ ${ }^{3}$ Centre for Isotope Research, University of Groningen, Nijenborgh 4, 9747 AG, Groningen, The Netherlands
}

\begin{abstract}
We compared the use of body stores in breeding Barnacle Geese (Branta leucopsis) in traditional Arctic colonies in the Barents Sea with that in recently established temperate-zone breeding colonies in the Baltic Sea and North Sea by studying female body-mass loss and use of fat and protein stores during incubation. Average daily body-mass loss was almost identical in the 2 temperatebreeding populations (17.0 g and $16.5 \mathrm{~g}$ in Baltic Sea and North Sea, respectively), whereas Arctic-breeding females lost significantly less $\left(10.6 \mathrm{~g} \mathrm{day}^{-1}\right)$. Temperate-breeding females initiated incubation with body mass $125 \mathrm{~g}$ higher than that of Arctic breeders, but at the end of incubation, body mass was similar among the 3 populations, averaging 1,458 g. Body-mass loss during incubation amounted to $23 \%$ (North Sea), 22\% (Baltic Sea), and 15\% (Barents Sea). Fat mass, as measured by isotope dilution in a subsample of females, was consistently higher in North Sea than in Barents Sea birds, but both populations showed similar rates of fat-mass loss $\left(9.4 \mathrm{~g}\right.$ day ${ }^{-1}$, on average). By contrast, loss of fat-free mass (assumed to represent wet protein) amounted to $9.3 \mathrm{~g}^{\text {day }}{ }^{-1}$ in North Sea birds but only $1.5 \mathrm{~g} \mathrm{day}^{-1}$ in Barents Sea birds. Energy content of $1 \mathrm{~g}$ utilized body mass was $21.1 \mathrm{~kJ}$ (North Sea) and $34.9 \mathrm{~kJ}$ (Barents Sea), which equates to $376 \mathrm{~kJ} \mathrm{day}^{-1}$ and $415 \mathrm{~kJ} \mathrm{day}^{-1}$ drawn from stored energy, respectively. We suggest that differences in nest-attendance and postincubation demands are responsible for the differential use of body stores in temperate- and Arctic-breeding Barnacle Geese. Received 1 November 2008, accepted 20 August 2009.
\end{abstract}

Key words: Barnacle Goose, body mass, body stores, Branta leucopsis, cost of reproduction, incubation, latitude, range expansion.

\section{Alimenter l'incubation : utilisation différentielle des réserves corporelles chez Branta leucopsis se reproduisant dans les régions arctiques et tempérées}

RÉSUMÉ.-Nous avons comparé l'utilisation des réserves corporelles chez des individus reproducteurs de Branta leucopsis dans les colonies traditionnelles de l'Arctique dans la mer de Barents avec celle de colonies récemment établies de la zone tempérée de la mer Baltique et de la mer du Nord. Pour ce faire, nous avons étudié la perte de la masse corporelle des femelles et l'utilisation des réserves de graisses et de protéines au cours de l'incubation. La perte quotidienne de la masse corporelle était en moyenne presque identique dans les 2 populations des régions tempérées (17,0 g et 16,5 g dans la mer Baltique et la mer du Nord, respectivement), alors que les femelles se reproduisant dans l'Arctique ont perdu significativement moins de poids $\left(10,6 \mathrm{~g}_{\text {jour }}{ }^{-1}\right)$. Les femelles des régions tempérées ont débuté l'incubation avec une masse corporelle plus élevée de $125 \mathrm{~g}$ par rapport à celle des femelles de l'Arctique. Toutefois, à la fin de l'incubation, la masse corporelle était similaire entre les 3 populations, soit en moyenne de $1458 \mathrm{~g}$. La perte de masse corporelle durant l'incubation atteignait $23 \%$ (mer du Nord), 22 \% (mer Baltique) et $15 \%$ (mer de Barents). La masse des graisses, telle que mesurée par une dilution isotopique dans un sous-échantillon de femelles, était constamment plus élevée chez les oiseaux de la mer du Nord que ceux de la mer de Barents. Néanmoins, les deux populations présentaient des taux de perte de la masse de graisses similaires $\left(9,4 \mathrm{~g}\right.$ jour ${ }^{-1}$, en

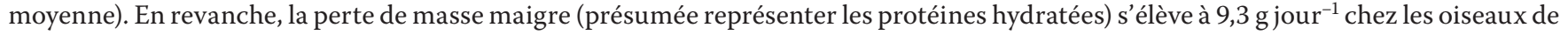
la mer du Nord, contre seulement $1,5 \mathrm{~g}_{\text {jour }}{ }^{-1}$ chez les oiseaux de la mer de Barents. Le contenu énergétique de $1 \mathrm{~g}$ de masse corporelle

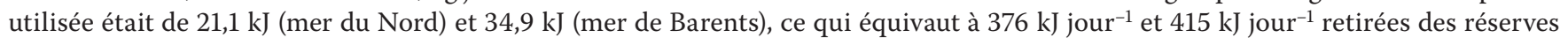
énergétiques, respectivement. Nous suggérons que les différences en termes d'assiduité au nid et des demandes post-incubation sont responsables de l'utilisation différentielle des réserves corporelles des individus de B. leucopsis des régions tempérées et arctiques.

${ }^{4}$ Present address: Institut Pluridisciplinaire H. Curien - Département Ecologie, Physiologie et Ethologie, Centre National de la Recherche Scientifique, Université de Strasbourg, 23 rue Becquerel, 67087 Strasbourg, France. E-mail: goetz.eichhorn@c-strasbourg.fr ${ }^{5}$ Deceased, 9 September 2008

The Auk, Vol. 127, Number 1, pages 162-172. ISSN 0004-8038, electronic ISSN 1938-4254. (C 2010 by The American Ornithologists' Union. All rights reserved. Please direct all requests for permission to photocopy or reproduce article content through the University of California Press's Rights and Permissions website, http://www.ucpressjournals. com/reprintInfo.asp. DOI: 10.1525/auk.2009.09057 
EVIDENCE OF THE adaptive significance of body stores for successful reproduction has been adduced for numerous species of waterfowl (reviewed by Arzel et al. 2006). In particular, female Arctic-nesting geese, which usually start nesting when local food resources are still scarce, depend on nutrients deposited earlier along the flyway (notably stores of fat and protein) to meet requirements for clutch production and incubation (Drent et al. 2007). Consequently, the amount of body stores available at laying has been suggested as the primary proximate determinant of clutch size in these birds (Alisauskas and Ankney 1992).

In addition to egg production, body stores are also needed for incubation, and, in some waterfowl, these stores represent virtually the only energy supply for the female during the entire incubation period (Thompson and Raveling 1987, Spaans et al. 1999, Bolduc and Guillemette 2003). Female body-mass loss during incubation can vary considerably among waterfowl, ranging from $3 \%$ to $33 \%$ among 24 anatid species with female-only incubation (Afton and Paulus 1992). It is thought that females retain additional stores as a buffer against unpredictable extra nutrient needs later in the reproductive cycle (Tombre and Erikstad 1996, Erikstad et al. 1998). Because of these multiple demands during a breeding cycle, the allocation of body stores to eggs, incubation, and care of chicks is subject to tradeoffs (Erikstad et al. 1993, Monaghan and Nager 1997). A consequence of insufficient stores may be that females, even if they are not forced to abandon the nest, must take more feeding recesses during incubation, which can increase the risk of egg predation and the length of the incubation period (Aldrich and Raveling 1983, Thompson and Raveling 1987, Tombre and Erikstad 1996). Finally, the tradeoff between current and future reproduction may be another factor that influences the extent to which body stores will be depleted (Erikstad et al. 1998). Indeed, some studies in which the incubation period was experimentally prolonged have reported negative effects on survival and future fecundity (Lessells 1986, Hanssen et al. 2005; but see Tombre and Erikstad 1996).

Intraspecific studies of body-stores use among populations that breed in different environments are necessary for a better understanding of reproductive tactics of waterfowl, but such studies have been scarce (Alisauskas and Ankney 1992, Rohwer 1992, Esler et al. 2001). For example, there is ample reason to speculate that temperate-breeding populations of geese differ from Arctic-breeding populations in their allocation of stores among the stages of the breeding cycle. The amount of body stores that a female has at the start of egg laying is determined both by the amount of stores it is able to carry from the staging areas (Ankney and MacInnes 1978) and by the amount of food available upon arrival on the breeding grounds (Prop and de Vries 1993, Choinière and Gauthier 1995, Ganter and Cooke 1996). Temperate-breeding geese may have an advantage over their Arctic counterparts in this respect because they have shorter migration routes and experience more favorable conditions before egg laying. Furthermore, because the breeding season is more prolonged farther south, populations there have more time to replenish lost stores, which may provide a further advantage. Finally, differences in thermoregulatory costs and predation risk between Arctic and temperate populations may also contribute to the extent to which body stores are depleted.

Our aim here is to verify such predictions for Arctic- and temperate-breeding populations of Barnacle Goose (Branta leucopsis). This species established temperate breeding colonies only about 3 decades ago, and the question of how a traditionally Arcticbreeding species could successfully adopt a temperate breeding strategy during such a short time span is intriguing (van der Jeugd et al. 2009). We studied female body-mass loss during incubation in 3 recently established populations, 1 Arctic (Barents Sea) and 2 temperate (Baltic Sea and North Sea) (Fig. 1). By means of isotope

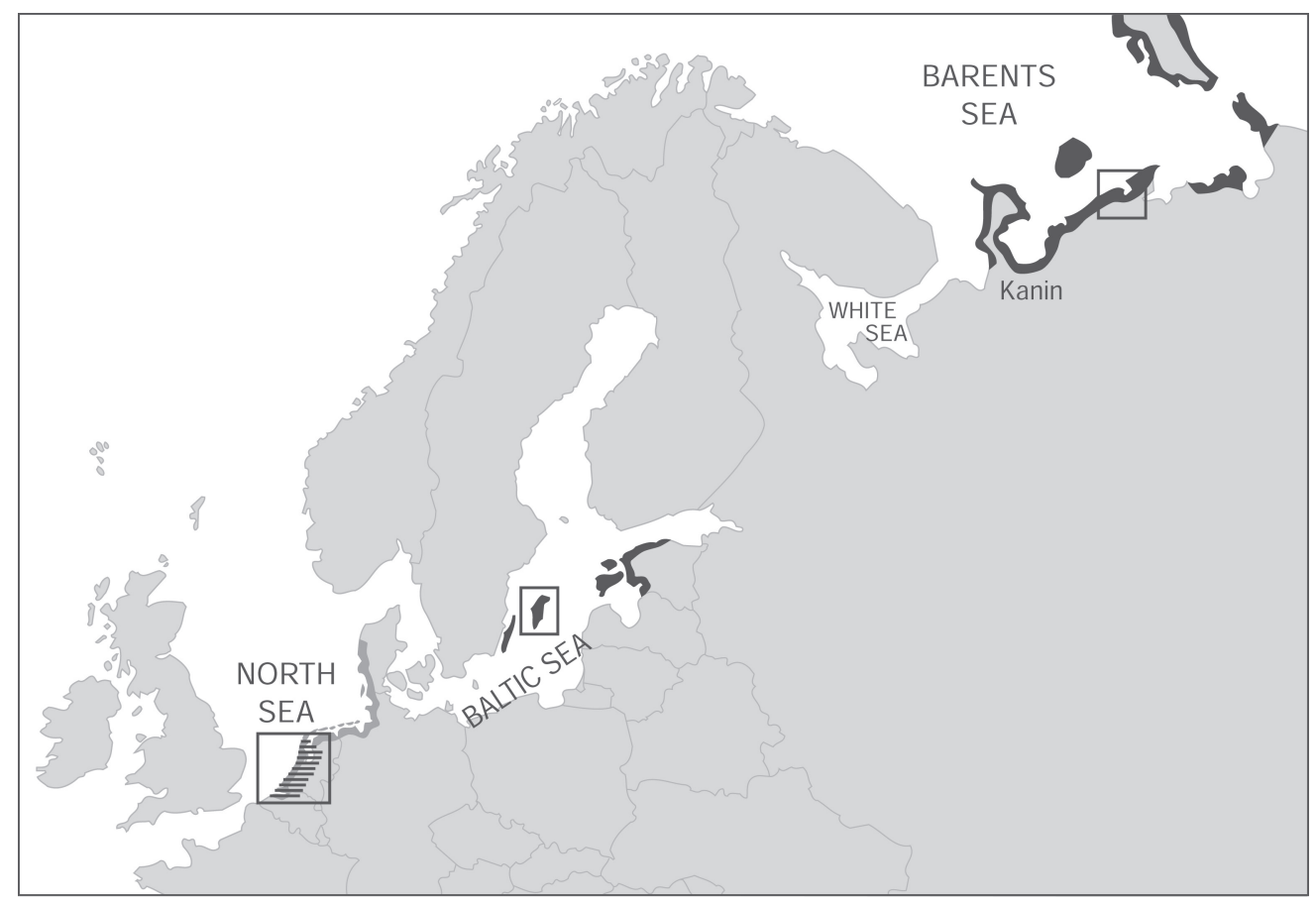

FIG. 1. Map showing the breeding (in black) and wintering (dark gray) distribution of Barnacle Geese from the North Sea-Baltic Sea-Barents Sea metapopulation and the location of the 3 study sites. 
TABLE 1. Summary of data used to model body-mass variation during incubation in female Barnacle Geese in 3 populations. Sample sizes $\left(n_{\mathrm{i}}=\right.$ measurements, $n_{\mathrm{j}}=$ individuals) for particular years are shown in the upper part of the table. Note that individual birds did not occur in more than 1 year in the data set. The lower part of the table gives means \pm SE for relevant covariables. Data were pooled for all available years, and if there were multiple values per bird within season (i.e., body mass and day of incubation), they were first averaged. The last two columns refer to results of analyses of variance testing for population differences ( $d f=2$ and 150$)$. Tukey post hoc test results (for $\alpha \leq 0.05$ ) are denoted by superscript letters.

\begin{tabular}{|c|c|c|c|c|c|c|c|c|}
\hline \multirow[b]{2}{*}{ Year } & \multicolumn{2}{|c|}{ Barents Sea } & \multicolumn{2}{|c|}{ Baltic Sea } & \multicolumn{2}{|c|}{ North Sea } & \multicolumn{2}{|c|}{ Total } \\
\hline & $n_{\mathrm{i}}$ & $n_{\mathrm{j}}$ & $n_{\mathrm{i}}$ & $n_{\mathrm{j}}$ & $n_{\mathrm{i}}$ & $n_{\mathrm{j}}$ & $n_{\mathrm{i}}$ & $n_{\mathrm{j}}$ \\
\hline 2000 & - & - & 14 & 14 & - & - & 14 & 14 \\
\hline 2003 & 25 & 25 & 4 & 4 & - & - & 29 & 29 \\
\hline 2004 & 38 & 22 & 73 & 36 & 12 & 7 & 123 & 65 \\
\hline 2005 & 27 & 17 & - & - & 40 & 28 & 67 & 45 \\
\hline Total & 90 & 64 & 91 & 54 & 52 & 35 & 233 & 153 \\
\hline \multicolumn{2}{|c|}{ Parameter } & \multicolumn{2}{|c|}{ Mean \pm SE } & Mean \pm SE & \multicolumn{2}{|c|}{ Mean \pm SE } & $F$ & $P$ \\
\hline \multicolumn{2}{|c|}{ Body mass [g] } & \multicolumn{2}{|c|}{$1,581 \pm 18^{a}$} & $1,650 \pm 23^{a}$ & \multicolumn{2}{|c|}{$1,728 \pm 27^{b}$} & 10.05 & $<0.001$ \\
\hline \multicolumn{2}{|c|}{ PC1 } & \multicolumn{2}{|c|}{$-0.13 \pm 0.11^{\mathrm{a}}$} & $-0.32 \pm 0.13^{a}$ & \multicolumn{2}{|c|}{$0.89 \pm 0.13^{b}$} & 21.48 & $<0.001$ \\
\hline \multicolumn{2}{|c|}{ Day of incubation } & \multicolumn{2}{|c|}{$14.2 \pm 0.6^{\mathrm{a}}$} & $11.5 \pm 0.7^{b}$ & \multicolumn{2}{|c|}{$12.4 \pm 0.9^{\mathrm{ab}}$} & 4.24 & 0.016 \\
\hline \multicolumn{2}{|c|}{ Clutch size } & \multicolumn{2}{|c|}{$4.0 \pm 0.1^{\mathrm{a}}$} & $4.8 \pm 0.1^{b}$ & \multicolumn{2}{|c|}{$5.0 \pm 0.2^{b}$} & 12.5 & $<0.001$ \\
\hline \multicolumn{2}{|c|}{ Lay date (April) } & \multicolumn{2}{|c|}{$72.5 \pm 0.6^{\mathrm{a}}$} & $26.3 \pm 0.6^{b}$ & \multicolumn{2}{|c|}{$23.3 \pm 0.9^{c}$} & 1,780 & $<0.001$ \\
\hline \multicolumn{2}{|c|}{ Standardized lay date } & \multicolumn{2}{|c|}{$0.21 \pm 0.14^{\mathrm{a}}$} & $-0.24 \pm 0.09^{b}$ & \multicolumn{2}{|c|}{$0.03 \pm 0.10^{\mathrm{ab}}$} & 3.76 & 0.026 \\
\hline
\end{tabular}

dilution, we were further able to distinguish between loss of fat and protein in a subsample of birds from the Barents Sea and the North Sea. We will show that large differences exist that invite speculation.

\section{Methods}

Study populations.-In the ancestral Barents Sea population, during 2003-2005, we studied body-mass loss in a colony on the northwest coast of Kolokolkova Bay, near the abandoned settlement of Tobseda, northern Russia $\left(68^{\circ} 35^{\prime} \mathrm{N}, 52^{\circ} 20^{\prime} \mathrm{E}\right)$. In the Baltic Sea population, in 2000, 2003, and 2004, we studied body-mass loss in the oldest and largest breeding colony, situated at Laus hol$\operatorname{mar}\left(57^{\circ} 17^{\prime} \mathrm{N}, 18^{\circ} 45^{\prime} \mathrm{E}\right)$ off the east coast of the island of Gotland, Sweden. In the North Sea population, in 2004 and 2005, we studied body-mass loss at Hellegatsplaten $\left(51^{\circ} 42^{\prime} \mathrm{N}, 4^{\circ} 20^{\prime} \mathrm{E}\right)$, one of the largest colonies ( $\sim 500$ pairs) situated on islands in the Delta area in the southwest of The Netherlands. More details on study sites and populations can be found in Eichhorn et al. (2009) and van der Jeugd et al. (2009) and references therein. Table 1 provides a summary of the data that we used to model body-mass variation.

Measurements of body mass, size and reproductive parameters.-Body mass of incubating females was measured by inserting a scale (type DE6K2, T.E.L.L., Germany) with a $31 \times 31 \mathrm{~cm}$ platform under the nest. This was done by removing a section of turf about $45 \times 45 \mathrm{~cm}$ across and $10-15 \mathrm{~cm}$ deep that contained the nest and placing the scale in the resulting hole. The nest was then carefully placed on top of the scale, which was fitted with an artificial nest cup (either styrene or wood) glued onto the platform. The remaining part of the scale was then covered by vegetation and soil, taking care that no material fell into the space between the fixed and moving parts and thereby ensuring that the weight could be recorded accurately. A digital display (linked to the scale by a flexible cable) was placed on a metal stand $\sim 1 \mathrm{~m}$ high at $\sim 5 \mathrm{~m}$ from the nest. The display could be read by a telescope from a distance of up to $\sim 200 \mathrm{~m}$. The observer would then retreat to an observation hide or sit concealed in the vegetation waiting for the female to return to the nest. When females did not return within $1 \mathrm{~h}$, the scale was removed and another female was selected. When the female was on the nest, the weight of nest and female was read from the display. The weight of the nest without the female was recorded immediately afterward when the female left the nest of her own accord or when the scale was collected. We attempted to weigh each individual at least twice, during the start and the end of the incubation period. Some females were weighed 3 times. In addition to using scales, some weights were obtained by trapping females on the nest using a remote-controlled clap net. In the Baltic in 2000 and 2003, all weights were gathered in this way and each female was weighed only once. All birds carried individually recognizable bands that were fitted previously or during nest captures. Body-size measurements were taken during nest captures or during previous mass banding drives and included tarsus length, measured with calipers to the nearest $0.1 \mathrm{~mm}$, and head length, measured with a ruler at 1-mm accuracy. Clutch size was determined during repeated visits to individual nests. In most nests, we marked individual eggs and could thus account for partial loss. Lay date (i.e., when the first egg was laid) was backdated from incomplete clutches found during egg laying, assuming a laying interval of $33 \mathrm{~h}$ (Alisauskas and Ankney 1992). Incubation was assumed to start with the last egg laid for clutches of $\leq 3$ eggs, and with the second-to-last egg for clutches of $>3$ eggs, but never later than the 5-egg stage. Clutches of $\geq 7$ eggs were very likely to have included parasitic eggs (Anderholm et al. 2009). We accounted for nest parasitism only if this became apparent during repeated nest 
visits (i.e., more eggs per interval than expected or additional eggs after clutch completion). Incubation duration in Barnacle Geese normally lasts 24 to 26 days (Dalhaug et al. 1996) but can range from 23 to 30 days (G. Eichhorn et al. pers. obs.). Our body-mass data covered days 2 to 25 of incubation.

Estimation offat and fat-free mass from isotope dilution.-We used deuterium isotope dilution (Speakman et al. 2001) to determine total body water (TBW) contents in a subsample of females from the Barents Sea (22 birds in 2003) and the North Sea (20 birds in 2005) during days 2 to 21 of incubation. Birds were trapped on the nest, injected intra-abdominally with a $99.9 \%$ deuterium isotope solution (Sigma-Aldrich, St. Louis, Missouri) using $1.0-\mathrm{mL}$ insulin syringes and sampled for blood from the brachial vein 90 min later. Samples were stored in flame-sealed microcapillary tubes. Birds were kept in cages with no access to food and drinking water during the isotope-dilution measurements. An equilibrium time of $90 \mathrm{~min}$ was sufficient to allow for adequate mixing of the marker solution with the birds' body-water pool (Eichhorn and Visser 2008). In the field, we always administered a dose of $1.0 \mathrm{~mL}$. In the laboratory, using an analytical balance (Mettler AG204) but the same type of syringes, we determined the average $( \pm \mathrm{SD})$ dose mass at $1.0 \mathrm{~mL}$ as $1.1153 \pm 0.0021 \mathrm{~g}(n=20)$. To estimate background levels of deuterium, blood samples were taken from 5 Barents Sea females and 4 North Sea females before isotope administration, and the respective averages were applied to birds at each study site. Determination of $\delta^{2} \mathrm{H}$ in blood samples was performed at the Center for Isotope Research, Groningen, The Netherlands (for details, see Eichhorn and Visser 2008). At least 3 internal water standards, chosen to cover the entire enrichment range of the blood samples, were prepared and analyzed using the same methods. All sample analyses were run at least twice, more times if values differed by $>2.5 \%$, and we used the average of values that differed from each other by $<2.5 \%$. Total body water determined from the dilution space (TBWd) was calculated by taking into account the quantity of the dose $\left(Q_{\mathrm{d}}, \mathrm{mol}\right)$, the ${ }^{2} \mathrm{H}$ concentration of the dose $\left(C_{\mathrm{d}}\right.$, atom $\left.\%\right)$, the ${ }^{2} \mathrm{H}$ background concentration $\left(C_{\mathrm{b}}\right.$, atom $\left.\%\right)$, and the ${ }^{2} \mathrm{H}$ concentration of individual blood samples $\left(C_{\mathrm{i}}\right.$, atom \%) using the following relationship:

$$
\text { TBWd }=18.02 \times Q_{\mathrm{d}} \times\left(C_{\mathrm{d}}-C_{\mathrm{i}}\right) /\left(C_{\mathrm{i}}-C_{\mathrm{b}}\right)
$$

TBWd systematically overestimates TBW (by 7.1\% in Barnacle Geese), and we predicted the latter according to TBW $=96.034+$ $0.852 \times$ TBWd $\left(r^{2}=0.976, P<0.001\right)$, established by Eichhorn and Visser (2008) for the same species. Assuming a water content in the fat-free mass of waterfowl of 66.6\% (Eichhorn and Visser 2008), the fat-free mass (FFM) was calculated as FFM $=\mathrm{TBW} / 0.666$, and fat mass (FM) was subsequently inferred from body mass (BM) as $\mathrm{FM}=\mathrm{BM}-\mathrm{FFM}$.

Calculation of energy equivalents.-We assumed that the loss of fat-free mass during incubation consisted almost entirely of loss of protein and water and that the potential loss of other constituents (carbohydrates and minerals) was negligible. We thus equated the loss of dry fat-free mass with protein loss. Physiological energy equivalents of fat and protein were taken at $39.3 \mathrm{~kJ} \mathrm{~g}^{-1}$ and $17.8 \mathrm{~kJ} \mathrm{~g}^{-1}$, respectively (Schmidt-Nielsen 1997). The energy equivalent for fat tissue was not corrected for water content (because this component is stored nearly free of water) but estimated at $4.5 \mathrm{~kJ} \mathrm{~g}^{-1}$ for wet protein, based on an average water content of $75 \%$ in the fat-free components of flight, leg, and gizzard muscles (Eichhorn 2008).

Estimating daily energy expenditure.-The resting metabolic rate (RMR; at night, post-absorptive) of Barnacle Geese was determined from oxygen consumption rates in 5 birds by Nolet et al. (1992) and in 4 birds by Stahl (2001). Combining data from both studies, we detected no effect of study or body mass (range: 1,650$2,876 \mathrm{~g})$ on RMR. Therefore, we apply the mean ( \pm SE) value of 5.59 $\pm 0.20 \mathrm{~J} \mathrm{~s}^{-1}(n=9)$ for further calculations here. Over the first 22 days of incubation, average daily recess time was 177 min for Barents Sea and 80 min for North Sea birds (Eichhorn 2008), and we used these values for the calculation of protein and energy budgets during steady incubation. For periods off the nest, we assumed an energy expenditure of 1.9 RMR regardless of study population (Afton and Paulus 1992, Stahl 2001). Average temperature during incubation was $12.4^{\circ} \mathrm{C}$ in the North Sea colony, and, assuming no costs for thermoregulation, we set energy expenditure while on eggs at 1.0 RMR for these birds. For Arctic-breeding birds, however, we should account for additional costs of thermoregulation. Stahl (2001) estimated that during average weather in January to April, the costs of maintenance metabolism can be subdivided into $52 \%$ for basal metabolic needs and $48 \%$ for thermoregulation in resting Barnacle Geese in their wintering area. The average temperature over this period $\left(4.1^{\circ} \mathrm{C}\right)$ is comparable with temperatures experienced by incubating Barnacle Geese in the Barents Sea colony $\left(4.5^{\circ} \mathrm{C}\right)$. However, by choosing a sheltered microhabitat, birds can notably reduce thermoregulation costs (Stahl 2001), and the insulated nest itself offers means to achieve such savings (Ar and Sidis 2002). Therefore, we assumed that thermoregulation costs accounted for an increase of $30 \%$ over the maintenance metabolism. Thus, energy expenditure while sitting on eggs resulted in 1.4 RMR for Barents Sea birds. This estimate is close to the 1.5 RMR applied by Afton and Paulus (1992) for geese and slightly lower than the 1.7 RMR empirically estimated for seabirds (Tinbergen and Williams 2002). Overall, we estimated a daily energy expenditure of $507 \mathrm{~kJ}$ and $743 \mathrm{~kJ}$ for North Sea and Barents Sea birds, respectively.

Statistics.-Individually marked birds with data for more than 1 season were entered in the data set only once, by selecting the season with most measurements or by random selection. To control for differences in structural size between females, we used principal component analysis for the full data set, including data from all 3 populations, to combine measurements of tarsus and head length to a single structural size variable, the first principal component (PC1), which explained $85 \%$ of the total variance. A second PC1 was calculated for a subsample of this data set that included measurements of fat and fat-free mass components in Barents Sea and North Sea populations. This PC1 explained 83\% of the total variance. To account for differences in the absolute value and the variance of lay dates among the Arctic and temperatezone populations (Table 1), we computed "standardized lay dates" as deviations from population-specific annual medians divided by the respective middle $50 \%$ range. Assumptions of normality and homogeneity of variances were evaluated using the KolmogorovSmirnov test and Levene's test, respectively. We used a generalized linear mixed-model procedure in MlwiN, version 2.0 (Rasbash et al. 2004), to account for interdependency between body-mass 
measurements taken on the same individuals during incubation within a given year. Variation of body mass was modeled using PC1, day of incubation, study population, year, standardized lay date, and clutch size (treated as a continuous variable) as explanatory variables. In the subsample that included data on fat and fatfree mass, each bird was measured only once, and we used analysis of covariance in SPSS software (SPSS, Chicago, Illinois) to test for variation of mass components depending on study population (fixed factor), with day of incubation and PC1 as covariates. Final models were derived by backward elimination of explanatory variables and their two-way interactions. All results are reported as means \pm SE and were considered significant at $P<0.05$.

\section{RESUlts}

Body mass.-Variation in body mass of incubating female Barnacle Geese was modeled from 233 individual measurements taken on 153 birds in 3 populations (Fig. 1 and Table 1). Differences in structural size (PC1) among birds in these populations were attributable to North Sea individuals generally being larger. Female body mass declined throughout incubation in all 3 populations, and, after accounting for size-dependent differences in body mass, the model revealed significant differences in the initial mass and in the daily rate of mass loss for Arctic and temperate breeders (Table 2). Average daily mass loss was almost identical in the temperate North Sea and Baltic populations, amounting to $17.0 \mathrm{~g}$ and $16.5 \mathrm{~g}$, respectively. Body-mass loss of females in the Arctic Barents Sea population was significantly lower, at $10.6 \mathrm{~g} \mathrm{day}^{-1}$. Temperate breeders initiated incubation at a body mass $125 \mathrm{~g}$ higher than that of Arctic females, which started incubation at 1,742 g. After 25 days of incubation, body mass converged to similar endpoints among the 3 populations, averaging 1,458 g. Clutch size, (standardized) lay date, and year showed no significant effect on body mass during incubation.
Fat,protein, andenergystores.-Results of thebody-composition analyses from isotope dilution in a subsample of 22 and 20 incubating females in the Barents Sea and North Sea populations, respectively, are summarized in Table 3 and Figure 2. The pattern for total body mass (Fig. 2A) resembles the findings from the larger data set, although population-specific differences in body mass were not statistically significant in this smaller subsample, which resulted in an average loss (for both populations) of $14.8 \mathrm{~g} \mathrm{day}^{-1}$ (Table 3A). Fat mass was significantly lower in Arctic breeders than in temperate (North Sea) breeders over the whole 20-day study period (65 g difference on average; Table 3B). However, females in both populations showed similar fat-mass depletion: $9.4 \mathrm{~g} \mathrm{day}^{-1}$, on average (Fig. 2B). By contrast, loss of fat-free mass (assumed to represent wet protein) differed significantly between populations, by $7.8 \mathrm{~g}$ (see interaction term "day_inc * population" in Table 3C). Temperate breeders depleted fat-free mass at $9.3 \mathrm{~g} \mathrm{day}^{-1}$, whereas the estimated loss of $1.5 \mathrm{~g} \mathrm{day}^{-1}$ for Arctic breeders was not significantly different from zero $(F=0.27, \mathrm{df}=1$ and $21, P=0.61$; Fig. $2 \mathrm{C})$. Accordingly, fat accounted for $86 \%$ and $50 \%$ of female body-mass loss in the Barents Sea and North Sea populations, respectively. Thus, compared with their Arctic conspecifics, temperate birds started incubation with higher levels of both fat and protein stores and retained more fat, but less protein, toward the end of incubation (note that in this data set, no values were obtained beyond day 21).

Energy density of wet protein is considerably lower than that of fat (see above). The estimated energy content of $1 \mathrm{~g}$ utilized body mass was $21.1 \mathrm{~kJ}$ in North Sea birds and $34.9 \mathrm{~kJ}$ in Barents Sea birds (calculated from the slopes in Fig. 2). Consequently, and despite the strong difference in body-mass loss, total energetic yields from body stores differed less between populations, amounting to $376 \mathrm{~kJ} \mathrm{day}^{-1}$ (North Sea) and $415 \mathrm{~kJ} \mathrm{day}^{-1}$ (Barents Sea). Of the estimated daily energy expenditure of $507 \mathrm{~kJ}$ and $743 \mathrm{~kJ}$ (see above), North Sea and Barents Sea birds, respectively, would have balanced $74 \%$ and $56 \%$ from their body stores.

TABLE 2. Model summary of body-mass loss during incubation (days 2-25; day_inc = day of incubation) of female Barnacle Geese in 3 populations. Parameter estimates $(B \pm S E)$ are given in relation to the Barents Sea population. Post hoc comparisons among populations refer to Wald tests.

\begin{tabular}{|c|c|c|c|c|c|}
\hline Final model & & $B \pm \mathrm{SE}$ & $d f$ & $\chi^{2}$ & $P$ \\
\hline Intercept & & $1,742 \pm 19.9$ & 1 & - & - \\
\hline PC1 & & $81.2 \pm 9.7$ & 1 & 69.7 & $<0.001$ \\
\hline Day_inc & & $-10.6 \pm 1.0$ & 1 & 104.8 & $<0.001$ \\
\hline \multirow[t]{2}{*}{ Population } & Baltic Sea & $124.4 \pm 26.7$ & 2 & 25.9 & $<0.001$ \\
\hline & North Sea & $125.1 \pm 32.5$ & - & - & - \\
\hline \multirow[t]{2}{*}{ Day_inc $*$ population } & Day_inc $*$ Baltic Sea & $-5.9 \pm 1.4$ & 2 & 23.2 & $<0.001$ \\
\hline & Day_inc $*$ North Sea & $-6.4 \pm 1.6$ & - & - & - \\
\hline Rejected terms & & - & - & - & - \\
\hline Year & & - & 3 & 1.15 & 0.77 \\
\hline Standardized lay date & & - & 1 & 0.61 & 0.43 \\
\hline Clutch size & & - & 1 & 0.46 & 0.50 \\
\hline \multicolumn{6}{|c|}{ Post hoc comparisons of populations } \\
\hline \multirow[t]{3}{*}{ Population } & North Sea-Baltic Sea & - & 1 & 0.00 & 1.00 \\
\hline & North Sea-Barents Sea & - & 1 & 14.80 & $<0.001$ \\
\hline & Baltic Sea-Barents Sea & - & 1 & 21.75 & $<0.001$ \\
\hline \multirow[t]{3}{*}{ Day_inc $*$ population } & North Sea-Baltic Sea & - & 1 & 0.12 & 0.73 \\
\hline & North Sea-Barents Sea & - & 1 & 15.87 & $<0.001$ \\
\hline & Baltic Sea-Barents Sea & - & 1 & 18.37 & $<0.001$ \\
\hline
\end{tabular}


TABLE 3. Results of analyses of covariance of total (A) body mass, (B) fat mass, and (C) fat-free body mass of incubating female Barnacle Geese. Mass loss during incubation, with day of incubation (day_inc) and PC1 as covariates, was compared between birds in the North Sea population $(n=20)$ and birds in the Barents Sea population (reference category; $n=$ 22). Differences in daily mass loss between North Sea and Barents Sea birds were tested by the interaction term day_inc * population. Nonsignificant terms were removed by backward deletion from the model and are in parentheses; $F$ values are given when included in the final model. Not shown are the parameters "clutch size" and "standardized lay date," which had no significant effect on any of the mass components.

\begin{tabular}{|c|c|c|c|c|}
\hline Parameter & $B \pm \mathrm{SE}$ & $d f$ & $F$ & $P$ \\
\hline \multicolumn{5}{|l|}{ (A) Body mass } \\
\hline Intercept & $1,852 \pm 31.3$ & 1 & 3,494 & $<0.001$ \\
\hline PC1 & $87.0 \pm 15.3$ & 1 & 32.48 & $<0.001$ \\
\hline Day_inc & $-14.8 \pm 2.3$ & 1 & 42.62 & $<0.001$ \\
\hline (Population) & - & 1 & 1.43 & 0.24 \\
\hline (Day_inc $*$ population) & - & 1 & 1.55 & 0.22 \\
\hline Final model $\left(R^{2}=0.64\right)$ & - & 2 & 34.25 & $<0.001$ \\
\hline Total & - & 41 & - & - \\
\hline \multicolumn{5}{|l|}{ (B) Fat mass } \\
\hline Intercept & $291.8 \pm 18.7$ & 1 & 352.9 & $<0.001$ \\
\hline$(\mathrm{PC} 1)$ & - & 1 & 0.19 & 0.66 \\
\hline Day_inc & $-9.4 \pm 1.2$ & 1 & 57.00 & $<0.001$ \\
\hline Population & $65.0 \pm 16.6$ & 1 & 15.33 & $<0.001$ \\
\hline (Day_inc $*$ population) & - & 1 & 0.40 & 0.53 \\
\hline Final model $\left(R^{2}=0.64\right)$ & - & 2 & 34.84 & $<0.001$ \\
\hline Total & - & 41 & - & - \\
\hline \multicolumn{5}{|l|}{ (C) Fat-free mass } \\
\hline Intercept & $1,505 \pm 33.3$ & 1 & 4,503 & $<0.001$ \\
\hline PC1 & $73.6 \pm 13.2$ & 1 & 30.96 & $<0.001$ \\
\hline Day_inc & $-1.5 \pm 2.3$ & 1 & 10.77 & 0.002 \\
\hline Population $^{\mathrm{a}}$ & $48.8 \pm 50.9$ & 1 & 0.92 & 0.34 \\
\hline Day_inc $*$ population & $-7.8 \pm 3.4$ & 1 & 5.29 & 0.027 \\
\hline Final model $\left(R^{2}=0.59\right)$ & - & 4 & 13.30 & $<0.001$ \\
\hline Total & - & 41 & - & - \\
\hline
\end{tabular}

a This parameter was retained in the final model (though its main effect was not significant) because of the significant interaction with day_inc.

\section{Discussion}

We found marked differences in the use of body stores during incubation between Arctic- and temperate-breeding female Barnacle Geese, with temperate breeders losing $\leq 60 \%$ more body mass each day. The loss of body stores, as quantified by isotope dilution in a subsample of birds, comprised mainly fat in Arctic-breeding females, whereas temperate breeders depleted both fat and protein stores significantly.

Body mass.-Assuming that the rates that we found were constant over the whole incubation period, female body-mass loss until the end of incubation (day 25) amounted to 15\% (Barents Sea), 22\% (Baltic Sea), and 23\% (North Sea). These values are conservative estimates, because few measurements were available for the first and last 2 days of incubation, when the rate of mass loss may have been even higher because of changing lipid and protein catabolism, a phenomenon that has been observed in fasting geese (Boismenu et al. 1992). Body mass after laying was not related
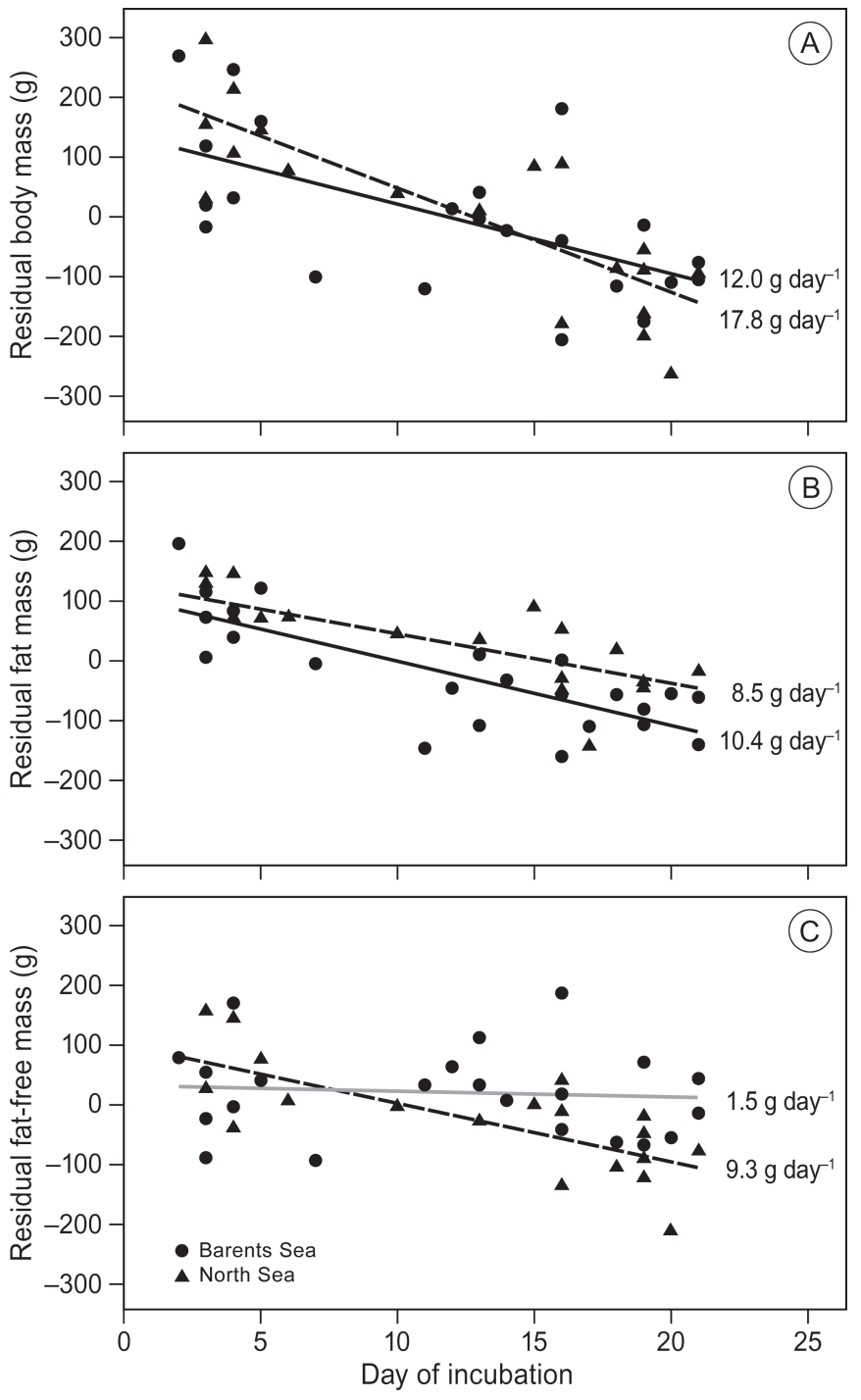

FIG. 2. Loss of (A) body mass, (B) fat mass, and (C) fat-free body mass during incubation among birds in the Barents Sea (solid line) and North Sea (broken line) breeding populations. Mass values represent residuals from a linear regression of mass against PC1. Values shown at the right refer to the estimated slopes of population-specific regression lines, which were significantly different from zero $(P<0.05)$ for all regressions except for residual fat-free mass of Barents Sea birds (solid gray line).

to clutch size or (standardized) lay date. Because clutch size decreased with (standardized) lay date $(F=4.98, \mathrm{df}=1$ and $149, P=$ 0.027 , accounting for population effects in the model), body mass at prelaying most likely decreased with lay date. If so, a parallel decline of both prelaying body mass and clutch size would cause a similar body mass after laying. Bêty et al. (2003) showed how Greater Snow Geese (scientific names are given in Table 4) might optimize individual egg-laying decisions (when and how many) according to their body condition. That females (of the same population) deplete their body stores during laying to similar levels at clutch completion regardless of clutch size has been observed, for instance, in Lesser Snow Geese, and is clearly adaptive for birds 
TABLE 4. Body-mass loss and nest attentiveness of northern geese during incubation. The numbers in front of species and subspecies names are used in Figure 3.

\begin{tabular}{|c|c|c|c|c|}
\hline Species or subspecies ${ }^{a}$ & $\begin{array}{c}\text { Body mass at start } \\
\text { of incubation (g) }\end{array}$ & $\begin{array}{l}\text { Body-mass } \\
\text { loss }(\%)\end{array}$ & $\begin{array}{l}\text { Time on } \\
\text { nest }(\%)\end{array}$ & $\begin{array}{l}\text { Energy stores to } \\
\text { incubation }^{\mathrm{b}}(\%)\end{array}$ \\
\hline (1) Greater Snow Goose (Chen caerulescens atlanticus) ${ }^{1}$ & 2,590 & 17 & $91.4-93$ & - \\
\hline (2) Lesser Snow Goose (C. c. caerulescens) & 2,530 & 32 & 97.1 & 78 \\
\hline (3) Emperor Goose (C. canagica) & 2,230 & 21 & 99.5 & - \\
\hline (4) Greater White-fronted Goose (Anser albifrons albifrons) ${ }^{2}$ & 2,635 & 24.1 & 99.2 & - \\
\hline (5) Western Canada Goose (Branta canadensis moffitti) & 4,300 & 27 & 97.5 & - \\
\hline (6) Dusky Canada Goose (B. c. occidentalis) & 3,206 & 22 & 91.7 & 58 \\
\hline (7) Cackling Canada Goose (B. c. minima) & 1,387 & 21 & 93.6 & 39 \\
\hline \multicolumn{5}{|l|}{ (8-12) Barnacle Goose (B. leucopsis) } \\
\hline (8) Great Britain population & 2,020 & 28 & 94.8 & - \\
\hline (9) North Sea population ${ }^{3}$ & 1,867 & 23 & 94.6 & 74 \\
\hline (10) Baltic Sea population ${ }^{3}$ & 1,866 & 22 & - & - \\
\hline (11) Barents Sea population ${ }^{3}$ & 1,742 & 15 & 89.1 & 56 \\
\hline (12) Spitsbergen population ${ }^{4}$ & - & - & $89.5-93.2$ & - \\
\hline (13) Dark-bellied Brant (B. bernicla bernicla $)^{5}$ & 1,269 & 16 & 87.6 & 52 \\
\hline (14) Light-bellied Brant (B. b. hrota) & 1,143 & 11 & 81.7 & 17 \\
\hline (15) Black Brant (B. b. nigricans $)^{6}$ & - & - & 89.6 & - \\
\hline
\end{tabular}

${ }^{a}$ Data are from Afton and Paulus (1992), updated for ${ }^{1}$ (Reed et al. 1995, Poussart et al. 2001), ${ }^{2}$ (Spaans et al. 1999), ${ }^{3}$ (present study, but nest attentiveness over 26 days of incubation taken from Eichhorn 2008), ${ }^{4}$ (89.9\% from Alsos et al. 1998; nest attentiveness as 89.5\% from Tombre and Erikstad 1996; $93.2 \%$ from I. M. Tombre et al. unpubl. data for 1997), ${ }^{5}$ (Spaans et al. 2007), and ${ }^{6}$ (Thompson and Raveling 1987).

${ }^{\mathrm{b}}$ Refers to the contribution of energy from body stores to total energy requirements during incubation, the remainder being met by food intake.

that draw mainly on body stores during incubation (Ankney and MacInnes 1978). Our results indicate that the postlaying bodystore threshold was similar within populations but different between them: temperate-breeding Barnacle Geese laid 1 egg more (Table 1); nevertheless, they commenced incubation with larger stores than birds in the Arctic population.

Protein and energy budgets.-Both lipid and protein depletion depend on energy expenditure. However, the ability to spare proteins during periods of fasting also depends on the amount of fat stores (Caloin 2004). Given the consistently higher fat mass and assuming lower energy expenditure in temperate-breeding females, their higher use of somatic protein cannot be caused by energetic demands. Instead, we suggest that the reduced feeding time of North Sea birds was insufficient to meet their protein requirements. For females from the same colonies, average daily recess time over the first 22 days of incubation was estimated as $177 \mathrm{~min}$ for Barents Sea birds, but it amounted to only $80 \mathrm{~min}$ for birds in the North Sea colony. Moreover, with 64\% (North Sea) and 77\% (Barents Sea) of recess time spent actually feeding (head below horizontal and grazing or seeking for food), daily feeding time for North Sea birds (51 min) would be only $38 \%$ as long as that of their Arctic conspecifics (136 min) (Eichhorn 2008). North Sea Barnacle Geese paid for their higher nest attentiveness by accepting a dry somatic protein loss of $2.3 \mathrm{~g} \mathrm{day}^{-1}$ (at $75 \%$ protein hydration; see above), whereas 85 min day $^{-1}$ of additional feeding allowed birds from the Barents Sea colony to keep their protein budget virtually in balance.

Barnacle Geese in both populations balanced most of their estimated daily energy expenditure from body stores. Balancing the remaining energy costs through feeding would demand intake rates of $1.6 \mathrm{~kJ} \mathrm{~min}^{-1}$ (North Sea) and $1.9 \mathrm{~kJ} \mathrm{~min}^{-1}$ (Barents Sea) off the nest (Appendix). This seems feasible if compared to the average rates of 1.5-2.4 $\mathrm{kJ} \mathrm{min}^{-1}$ found for Barnacle Geese foraging in different habitats during spring (Prop and Black 1998). There are only a few previous estimates of the contribution of endogenous stores to total incubation cost (Table 4), and these do not reveal a simple pattern in, for instance, breeding latitude or body mass (see also Thompson and Raveling 1987).

When the daily rates of fat-stores depletion have been determined between day 2 and day 21 (Table 3 and Fig. 2) and are applied to the entire 25-day incubation period, we estimate that in Arctic birds, $260 \mathrm{~g}$ of the original fat mass of $292 \mathrm{~g}$ would be depleted during incubation, leaving a residue of $32 \mathrm{~g}$ at hatch. These figures corroborate the provisional fat budget for Russian birds presented by Drent et al. (2007), in which the fat mass at commencement of incubation was estimated as $310 \mathrm{~g}$ (and, hence, the residue at hatch was slightly greater than in the present study). The nonmigratory temperate counterparts in the North Sea would have depleted their fat mass by $213 \mathrm{~g}$, from $357 \mathrm{~g}$ at the start to $144 \mathrm{~g}$ at hatch (see Appendix for calculations of related figures).

Although these figures require confirmation by sampling of females at hatch, the preliminary calculations support the notion that females in the Arctic work to a stringent budget and must supplement their endogenous energy source by feeding throughout incubation to avoid complete depletion of their fat stores. In this view, the time off the nest is adjusted to ensure the exogenous energy input needed to balance the budget. Because the temperate breeders commence incubation with higher fat stores and, moreover, face lower daily costs, they can reduce their daily feeding time compared with their Arctic counterparts. Table 4 shows that attentiveness during incubation (percentage of time on nest) is consistently higher in Barnacle Geese that incubate in temperate regions than in Arctic populations, by a margin of $\leq 5 \%$. Relating species or population means of body-mass loss to nest attentiveness underlines the importance of incubation recesses for the regulation of body stores (Fig. 3). Furthermore, the pattern illustrated here suggests accelerated loss of body mass with increasingly higher nest attentiveness. This may be attributable to relatively more protein depletion and an increased risk of entering 


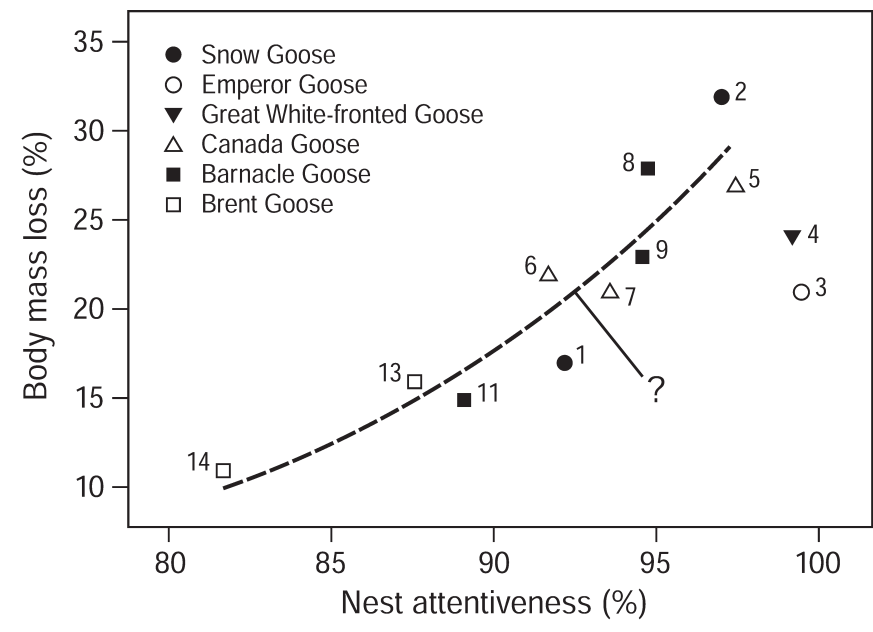

FIG. 3. Body-mass loss during incubation in relation to nest attentiveness. Species of geese are marked by common symbols. Numbers refer to taxa as presented in Table 4. A hypothetical fit is shown by a dashed line fitted through all data points except 3 and 4.

phase III of starvation at high nest attentiveness (Boismenu et al. 1992). Two studies, on Emperor and White-fronted geese, "fall off the line" and may require confirmation (results of the latter study were based on a sample size of 1 ).

Alsos et al. (1998) showed that individual female Barnacle Geese with rich food supplies in their feeding territory exhibited greater attentiveness than neighbors with fewer resources, which again suggests that time off to feed is regulated to achieve a given energetic or nutritional intake. Prop et al. (1984) showed that individual Barnacle Geese that abandoned incubation spent increasing amounts of time feeding daily, which suggests that these birds were in poor body condition and needed to compensate for this (see also Schmutz et al. 2006). Aldrich and Raveling (1983) studied incubation attentiveness in 13 pairs of captive (and wing-clipped) Western Canada Geese kept in large flight pens in California. Females were weighed at the onset, and thereafter at weekly intervals. Overall attentiveness was $97.5 \%$ (and the birds lost $27 \%$ of initial body mass), but the individual data showed that total recess time during incubation was related to body mass at onset, a relation also evident on a weekly basis. As expected, mass loss between weighings depended on weekly recess time: individuals with shorter feeding times experienced greater losses of body mass. These three studies on individual incubation constancy support the notion that feeding time is adjusted, in the short term, in relation to the state of the body stores.

Factors explaining population differences.-We identified nest attentiveness as one proximate reason for the differences in use of body stores among Arctic- and temperate-breeding Barnacle Geese. Weather conditions, feeding conditions, and predation pressure have been suggested as factors that regulate incubation behavior in geese (e.g., Aldrich and Raveling 1983, Thompson and Raveling 1987, Poussart et al. 2001, Jónsson et al. 2007). Barnacle Geese in the North Sea colony enjoy milder temperatures than those breeding at the Barents Sea coast (Eichhorn 2008), which likely reduces the costs of maintaining body temperature and reheating the clutch after incubation recesses. Feeding conditions, as judged by the nitrogen content of food plants, appeared to be comparable among study sites (van der Jeugd et al. 2009), and predation pressure on unattended clutches actually seemed to be lower in the North Sea colonies (G. Eichhorn et al. pers. obs.). Thus, these factors can hardly explain the higher nest attendance of birds in the North Sea colony. Further work will be needed to quantify other factors in the nest-attendance tradeoff (e.g., protection from egg dumping).

Females may balance their stores to ensure that they are not completely exhausted until hatch. Female Barnacle Geese breeding on Spitsbergen with experimentally prolonged incubation (5 days) did not increase recess time during late incubation but sacrificed body condition instead, which suggests that they had extra stores at the end of the normal incubation period as a safeguard against unpredictable conditions (Tombre and Erikstad 1996). With an estimated fat residue of $32 \mathrm{~g}$ at hatch and a daily fat loss of $10 \mathrm{~g}$, our Barents Sea birds would have been unable to incubate for another 5 days unless they notably increased their food uptake. Apparently, nest attentiveness is maximized as permitted by the amount of body stores allocated to incubation.

The degree to which females exhaust their body stores during incubation also likely depends on the demands of the postincubation period, such as an increased input of dietary protein for feather synthesis during postbreeding molt (e.g., Hohman et al. 1992). These demands may differ between Arctic- and temperatebreeding Barnacle Geese. Although birds in all 3 populations usually undergo molt on their breeding grounds, Barents Sea birds also have to prepare for a 3,200-km fall migration, whereas the temperate breeders overwinter in or relatively near their breeding and molting grounds. Arctic birds are therefore subject to greater time constraints during the postbreeding period. The interval between hatching (when body stores are at an all-year low) and the start of molt is $~ 35$ days in the Baltic and North seas but only 16 days in the Barents Sea (van der Jeugd et al. 2009). Moreover, a preliminary comparison showed that body mass during molt declined $3 \times$ as rapidly in Barents Sea birds as in Baltic Sea birds (van der Jeugd et al. 2003), although growth rates of the ninth primary feather did not differ between these populations (van der Jeugd et al. 2009). Finally, long-distance migration requires the deposition of significant amounts of protein as well as fat (e.g., Lindström and Piersma 1993, Prop and Black 1998). We suspect that these postincubation demands significantly influence the allocation of body stores to incubation. According to this interpretation, Arcticbreeding females regulate their daily intake of protein to avoid depletion of their body stores during incubation and, thus, accept longer daily feeding times. Extending our knowledge of body composition to embrace the post-incubation period will further our understanding of the allocation of body stores in geese.

\section{ACKNOWLEDGMENTS}

We thank J. Anisimov, D. Ochinashko, M. Schouten, A. Pouw, and J. van Dijk for their help in the field. B. Verstappen-Dumoulin determined the ${ }^{2} \mathrm{H}$ enrichments. K. Litvin and M. van Eerden played an important role in organizing and supporting the Dutch-Russian expeditions to Tobseda. Further support by the Institute of Biology in Syktyvkar, by the administrations of the Nenets Autonomous District and the State Nature reserve Nenetskiy, and by the Russian Hunters Association is gratefully acknowledged. K. Larsson 
logistically supported the studies on Gotland in 2003 and 2004 and kindly supplied body-mass measurements of incubating females taken there in 2000. The study at Hellegatsplaten, The Netherlands, was made possible by the support of the owner, Staatsbosbeheer. Valuable comments by M. Klaassen, R. Ydenberg, J. Black, and one anonymous reviewer improved the manuscript. D. Visser helped with the preparation of figures. Financial assistance came from the Dutch Institute for Inland Water Management and Waste Water Treatment (RIZA), the Schure-Beijerink-Popping Fonds (KNAW - Royal Netherlands Academy of Arts and Sciences), and the Nicolaas Mulerius Fonds of the University of Groningen. G.E. was supported by travel grants from the European Science Foundation (BIRD Programme) and scholarships from the Marianne und Dr. Fritz Walter-Fischer Stiftung, Germany, and the Ubbo Emmius Programme at the University of Groningen.

\section{Literature Cited}

Afton, A. D., and S. L. Paulus. 1992. Incubation and brood care. Pages 62-108 in Ecology and Management of Breeding Waterfowl (B. D. J. Batt, A. D. Afton, M. G. Anderson, C. D. Ankney, D. H. Johnson, J. A. Kadlec, and G. L. Krapu, Eds.). University of Minnesota Press, Minneapolis.

Aldrich, T. W., AND D. G. Raveling. 1983. Effects of experience and body weight on incubation behavior of Canada Geese. Auk 100:670-679.

Alisauskas, R. T., And C. D. AnKney. 1992. Egg laying and nutrient reserves. Pages 30-61 in Ecology and Management of Breeding Waterfowl (B. D. J. Batt, A. D. Afton, M. G. Anderson, C. D. Ankney, D. H. Johnson, J. A. Kadlec, and G. L. Krapu, Eds.). University of Minnesota Press, Minneapolis.

Alsos, I. G., A. ElvebaKk, And G. W. Gabrielsen. 1998. Vegetation exploitation by Barnacle Geese Branta leucopsis during incubation on Svalbard. Polar Research 17:1-14.

Anderholm, S., R. C. Marshall, H. P. van der Jeugd, P. WalDeCK, K. LARsSon, And M. Andersson. 2009. Nest parasitism in the Barnacle Goose: Evidence from protein fingerprinting and microsatellites. Animal Behaviour 78:167-174.

AnKney, C. D., And C. D. MaCInnes. 1978. Nutrient reserves and reproductive performance of female Lesser Snow Geese. Auk 95:459-471.

AR, A., AND Y. SIDIS. 2002. Nest microclimate during incubation. Pages 143-160 in Avian Incubation: Behaviour, Environment and Evolution (D. C. Deeming, Ed.). Oxford University Press, Oxford, United Kingdom.

Arzel, C., J. Elmberg, And M. Guillemain. 2006. Ecology of spring-migrating Anatidae: A review. Journal of Ornithology 147:167-184.

Bêty, J., G. Gauthier, and J.-F. Giroux. 2003. Body condition, migration, and timing of reproduction in Snow Geese: A test of the condition-dependent model of optimal clutch size. American Naturalist 162:110-121.

Boismenu, C., G. Gauthier, and J. Larochelle. 1992. Physiology of prolonged fasting in Greater Snow Geese (Chen caerulescens atlantica). Auk 109:511-521.

Bolduc, F., AND M. Guillemette. 2003. Incubation constancy and mass loss in the Common Eider Somateria mollissima. Ibis 145:329-332.
Caloin, M. 2004. Modeling of lipid and protein depletion during total starvation. American Journal of Physiology - Endocrinology and Metabolism 287:E790-E798.

ChOINiÈre, L., AND G. GAuthier. 1995. Energetics of reproduction in female and male Greater Snow Geese. Oecologia 103:379-389.

Dalhaug, L., I. M. Tombre, and K. E. Erikstad. 1996. Seasonal decline in clutch size of the Barnacle Goose in Svalbard. Condor 98:42-47.

Drent, R. H., G. Eichhorn, A. Flagstad, A. J. van der GraAf, K. E. Litvin, AND J. STAHL. 2007. Migratory connectivity in Arctic geese: Spring stopovers are the weak links in meeting targets for breeding. Journal of Ornithology 148 (Supplement 2):501-514.

EICHHORN, G. 2008. Travels in a changing world: Flexibility and constraints in migration and breeding of the Barnacle Goose. Ph.D. dissertation, University of Groningen, Groningen, The Netherlands.

Eichhorn, G., R. H. Drent, J. Stahl, A. Leito, and T. AlerSTAM. 2009. Skipping the Baltic: The emergence of a dichotomy of alternative spring migration strategies in Russian Barnacle Geese. Journal of Animal Ecology 78:63-72.

EICHHORN, G., AND G. H. VISSER. 2008. Evaluation of the deuterium dilution method to estimate body composition in the Barnacle Goose: Accuracy and minimum equilibration time. Physiological and Biochemical Zoology 81:508-518.

Erikstad, K. E., J. O. Bustnes, And T. Moum. 1993. Clutch-size determination in precocial birds: A study of the Common Eider. Auk 110:623-628.

Erikstad, K. E., P. Fauchald, T. Tveraa, and H. Steen. 1998. On the cost of reproduction in long-lived birds: The influence of environmental variability. Ecology 79:1781-1788.

Esler, D., J. B. Grand, AND A. D. Afton. 2001. Intraspecific variation in nutrient reserve use during clutch formation by Lesser Scaup. Condor 103:810-820.

Ganter, B., And F. COOKE. 1996. Pre-incubation feeding activities and energy budgets of Snow Geese: Can food on the breeding grounds influence fecundity? Oecologia 106:153-165.

Hanssen, S. A., D. Hasselquist, I. Folstad, and K. E. Erikstad. 2005. Cost of reproduction in a long-lived bird: Incubation effort reduces immune function and future reproduction. Proceedings of the Royal Society of London, Series B 272:1039-1046.

Hohman, W. L., C. D. ANKNeY, AND D. H. Gordon. 1992. Ecology and management of postbreeding waterfowl. Pages 128-189 in Ecology and Management of Breeding Waterfowl (B. D. J. Batt, A. D. Afton, M. G. Anderson, C. D. Ankney, D. H. Johnson, J. A. Kadlec, and G. L. Krapu, Eds.). University of Minnesota Press, Minneapolis.

Jónsson, J. E., A. D. Afton, And R. T. Alisauskas. 2007. Does body size influence nest attendance? A comparison of Ross's Geese (Chen rossii) and the larger, sympatric Lesser Snow Geese (C. caerulescens caerulescens). Journal of Ornithology 148:549555.

Lessells, C. M. 1986. Brood size in Canada Geese: A manipulation experiment. Journal of Animal Ecology 55:669-690.

LindströM, Å., AND T. Piersma. 1993. Mass changes in migrating birds: The evidence for fat and protein storage re-examined. Ibis 135:70-78.

Monaghan, P., and R. G. Nager. 1997. Why don't birds lay more eggs? Trends in Ecology and Evolution 12:270-274. 
Nolet, B. A., P. J. Butler, D. Masman, And A. J. WoAkes. 1992. Estimation of daily energy expenditure from heart rate and doubly labeled water in exercising geese. Physiological Zoology 65:1188-1216.

Poussart, C., G. Gauthier, and J. Larochelle. 2001. Incubation behaviour of Greater Snow Geese in relation to weather conditions. Canadian Journal of Zoology 79:671-678.

Prop, J., AND J. M. BLACK. 1998. Food intake, body reserves and reproductive success of Barnacle Geese Branta leucopsis staging in different habitats. Norsk Polarinstitutt Skrifter 200:175-193.

Prop, J., AND J. DE VRIEs. 1993. Impact of snow and food conditions on the reproductive performance of Barnacle Geese Branta leucopsis. Ornis Scandinavica 24:110-121.

Prop, J., M. R. van Eerden, and R. H. Drent. 1984. Reproductive success of the Barnacle Goose Branta leucopsis in relation to food exploitation on the breeding grounds, western Spitsbergen. Norsk Polarinstitutt Skrifter 181:87-117.

Rasbash, J., F. Steele, W. Browne, and B. Prosser. 2004. A User's Guide to MlwiN, version 2.0. Centre for Multilevel Modelling, London.

Reed, A., R. J. Hughes, And G. Gauthier. 1995. Incubation behavior and body mass of female Greater Snow Geese. Condor 97:993-1001.

Rohwer, F. C. 1992. The evolution of reproductive patterns in waterfowl. Pages 486-539 in Ecology and Management of Breeding Waterfowl (B. D. J. Batt, A. D. Afton, M. G. Anderson, C. D. Ankney, D. H. Johnson, J. A. Kadlec, and G. L. Krapu, Eds.). University of Minnesota Press, Minneapolis.

Schmidt-Nielsen, K. 1997. Animal Physiology: Adaptation and Environment, 5th ed. Cambridge University Press, Cambridge, United Kingdom.

Schmutz, J. A., K. A. Hobson, And J. A. Morse. 2006. An isotopic assessment of protein from diet and endogenous stores: Effects on egg production and incubation behaviour of geese. Ardea 94:385-397.
SpaAns, B., W. van der Veer, ANd B. S. EbBinge. 1999. Cost of incubation in a Greater White-fronted Goose. Waterbirds 22:151-155.

Spaans, B., C. A. van't Hoff, W. van der Veer, and B. S. EbbINGE. 2007. The significance of female body stores for egg laying and incubation in dark-bellied brent geese Branta bernicla bernicla. Ardea 95:3-15.

Speakman, J. R., G. H. Visser, S. Ward, and E. Król. 2001. The isotope dilution method for the evaluation of body composition. Pages 56-98 in Body Composition Analysis of Animals: A Handbook of Non-Destructive Methods (J. R. Speakman, Ed.). Cambridge University Press, Cambridge, United Kingdom.

STAHL, J. 2001. Limits to the co-occurence of avian herbivores: How geese share scarce resources. Ph.D. dissertation, University of Groningen, Groningen, The Netherlands.

Thompson, S. C., And D. G. Raveling. 1987. Incubation behavior of Emperor Geese compared with other geese: Interactions of predation, body size, and energetics. Auk 104:707-716.

Tinbergen, J. M., And J. B. Williams. 2002. Energetics of incubation. Pages 299-313 in Avian Incubation: Behaviour, Environment and Evolution (D. C. Deeming, Ed.). Oxford University Press, Oxford, United Kingdom.

Tombre, I. M., And K. E. ERIKSTAD. 1996. An experimental study of incubation effort in high-Arctic Barnacle Geese. Journal of Animal Ecology 65:325-331.

van der Jeugd, H. P., G. Eichhorn, K. E. Litvin, J. Stahl, K. Larsson, A. J. van der Graaf, and R. H. Drent. 2009. Keeping up with early springs: Rapid range expansion in an avian herbivore incurs a mismatch between reproductive timing and food supply. Global Change Biology 15:1057-1071.

van der Jeugd, H. P., E. Gurtovaya, G. Eichhorn, K. Ye. Litvin, O. Y. MineEv, ANd M. van Eerden. 2003. Breeding Barnacle Geese in Kolokolkova Bay, Russia: Number of breeding pairs, reproductive success and morphology. Polar Biology 26:700-706.

Associate Editor: S. R. McWilliams 
ApPENDIX. Incubation fact sheet for Barnacle Geese from the Barents Sea and the North Sea. Given are measured mean values or values derived from calculations. Abbreviations: $B M=$ body mass, $F M=$ fat mass, $F F M=$ fat-free mass, $R M R=$ resting metabolic rate, and DEE = daily energy expenditure.

\begin{tabular}{|c|c|c|c|}
\hline & Barents Sea & North Sea & Remark \\
\hline Clutch size & 4.0 & 5.0 & - \\
\hline Incubation duration (days) & $25(22-26)$ & $25(22-26)$ & Dalhaug et al. 1996 \\
\hline Time off nest per day (min) & 157 & 78 & Whole incubation period (26 days) \\
\hline Time off nest per day (min) & 177 & 80 & Over first 22 days of incubation \\
\hline BM at start of incubation (g) & 1,742 & 1,867 & Full data set on BM \\
\hline Daily mass loss BM (g) & 10.6 & 17.0 & Full data set on BM \\
\hline Daily mass loss BM (g) & 12.0 & 17.8 & Subsample for body composition \\
\hline Daily mass loss FM (g) & 10.4 & 8.5 & Subsample for body composition \\
\hline Daily mass loss FFM (g) & 1.5 & 9.3 & Subsample for body composition \\
\hline \multicolumn{4}{|c|}{ Energy budget } \\
\hline $\operatorname{RMR}\left(\mathrm{kJ} d a y^{-1}\right)$ & 483 & 483 & For BM at half-way incubation \\
\hline DEE in RMR units & 1.7 & 1.1 & - \\
\hline Estimated DEE $\left(\mathrm{kJ}\right.$ day $\left.^{-1}\right)$ & 743 & 507 & - \\
\hline Energy from body $\left(\mathrm{kJ} \mathrm{day}^{-1}\right)$ & 415 & 376 & - \\
\hline Shortfall $\left(k J\right.$ day $\left.^{-1}\right)$ & 328 & 131 & - \\
\hline Net intake needed $\left(\mathrm{kJ} \mathrm{day}^{-1}\right)$ & 1.9 & 1.6 & - \\
\hline Contribution from body (\%) & 56 & 74 & - \\
\hline \multicolumn{4}{|c|}{ FM dynamics } \\
\hline At day $0(\mathrm{~g})$ & 292 & 357 & - \\
\hline Depletion over 25 days (g) & 260 & 213 & - \\
\hline At hatch $(g)$ & 32 & 144 & Day 25 of incubation \\
\hline \multicolumn{4}{|c|}{ FFM dynamics } \\
\hline At day $0(\mathrm{~g})$ & 1,505 & 1,554 & - \\
\hline Depletion over 25 days (g) & 38 & 233 & - \\
\hline At hatch $(\mathrm{g})$ & 1,467 & 1,321 & Day 25 of incubation \\
\hline FFM + FM at hatch $(\mathrm{g})$ & 1,499 & 1,465 & Day 25 of incubation \\
\hline
\end{tabular}

